\title{
Dilma Rousseff's Third Round
}

\author{
O terceiro turno de Dilma Rousseff
}

João Feres Júnior', Luna de Oliveira Sassara²

\begin{abstract}
In this paper, we test the hypothesis that the news media coverage of President Dilma Rousseff in the newspapers 'Folha de São Paulo', 'O Globo' and 'O Estado de São Paulo' became increasingly negative after her victory in the 2014 elections. We also compare her coverage with that of senator Aécio Neves, her main opponent in the last election, president of PSDB and leader of the opposition, who has been accused of corruption several times after the election. The test clearly shows that the Brazilian media is highly politicized. We conclude the article by discussing the importance of the media for the future of democracy in Brazil.
\end{abstract}

KEYWORDS Democracy. Press. Brazil. Politics.

RESUMO Neste artigo, testamos a hipótese de que a cobertura recebida pela presidente Dilma Rousseff nos jornais 'Folha de São Paulo', 'O Globo' e 'O Estado de São Paulo' tornou-se ainda mais negativa após sua vitória eleitoral em outubro de 2014. Também comparamos a cobertura de Dilma àquela dedicada a Aécio Neves, seu principal adversário e líder da oposição, alvo de inúmeras denúncias de corrupção no período pós-eleitoral. O teste não deixa dúvidas acerca do caráter altamente politizado da mídia brasileira. Concluímos refletindo sobre a importância da mídia para o futuro da democracia no Brasil.

PALAVRAS-CHAVE Democracia. Imprensa. Brasil. Política.

\footnotetext{
1 Universidade do Estado do Rio de Janeiro (Uerj), Instituto de Estudos Sociais e Políticos (lesp) - Rio de Janeiro (RJ), Brasil.

jferes@iesp.uerj.br

2 Universidade Federal do Estado do Rio de Janeiro (Unirio) - Rio de Janeiro (RJ), Brasil.

lunasassara@gmail.com
} 
Art. 77. The election of the President and

Vice-President of the Republic shall take place simultaneously, on the first Sunday of

October, in the first round, and on the last Sunday of October, in the second round, as the case may be, of the year preceding the one in which the current presidential term of office ends.

Constitution of the Federative Republic of Brazil, 1988

\section{Introduction}

Studies on media and on elections in Brazil have identified a repeated inclination of the main communications network towards a negative media coverage of left-wing candidates in the Brazilian presidential elections (ARRUDA, 1995; FIGUEIREDO, 1996; GONÇALVES, 1996; KUCINSKI, 1998; MIGUEL, 1999; AZEVEDO, 2000; COLLING, 2000; MIGUEL, 2002). The news media frequently tries to defend itself against accusations of political bias arguing that such behavior is simply the result of surveillance of political power in favor of the interests of society - a role that must be played by the press in modern democracies and that is called 'watchdog'. In a previous work, we have already shown that, unlike what is said, the great national media does not act as a watchdog regarding the center or right-wing candidates (FERES JÚNIOR; SASSARA, 2016).

Therefore, researchers of political communications have a very important role - to watch the supposed watchdog, that is, to critically observe the media's work. Thus, during the 2014 Brazilian election campaign, the group from the Laboratory of Media Studies and Public Sphere (Laboratório de Estudos de Mídia e Esfera Pública - Lemep), located at the Institute of Social and Political Studies (Instituto de Estudos Sociais e Políticos) of the State University of Rio de Janeiro (Iesp-Uerj), launched the website Manchetômetro (Headline Checker) (http:// manchetometro.com.br), which was aimed at observing the daily press coverage of the main candidates and parties involved in Brazil's presidential dispute by the main Brazilian media, namely the newspapers 'Folha de São Paulo', 'O Globo' and 'O Estado de São Paulo' ('Estadão'), and the TV news program called Jornal Nacional'.

The majority of the studies on media and politics conducted in the Brazilian academy are concentrated in election periods. This is also true for the Manchetômetro in its initial stage, as it was created to reproduce 'realtime' analyses of the election coverage. In this paper, we tried to broaden the analysis scope for the period after the election, so as to reveal the media's role in the political crisis that has worsen after the re-election of Dilma Rousseff, which we call here the 'third round', and which has led to her losing the mandate. The hypothesis that we examine is that in the months following the election, differently from what the literature predicts, the main Brazilian newspapers, in the wake of the political events led by the opposition, conducted an extremely hostile campaign against the President Dilma Rousseff.

The analyses of this paper were performed based on the database of the Manchetômetro, from the beginning of 2014 until today $^{2}$. Up to August 27, 2016, the date chosen by us to conclude the database, there was a total of 35,049 encoded articles published in the newspapers 'Folha de São Paulo', 'Estadão', 'O Globo' and 'Estado de Minas'. In the case of the newspapers, we took into account what is published in the covers and opinion pages. Regarding TV Globo's Jornal Nacional, we analyzed the entire program. In the current work, we only took into account the texts published in the covers of the following newspapers: 'Folha de São Paulo', 'Estadão' and 'O Globo'.

In graph 1 below, we show the number of articles about President Dilma Rousseff published in the media we searched throughout the period of our database, separated by their valences.

\footnotetext{
1 The data on the coverage of Jornal Nacional will not be shown in this paper, but they have already been presented in previous works (see FERES JÚNIOR; SASSARA, 2014, 2016; FERES JÚNIOR et al., 2016). The data are also available on our website.

2 In fact, the website also shows the data about the elections in 1998 and 2010. We are currently increasing the size of the database to also include the analysis of the mainstream newspapers for the year of 2013 , within the scope of a project about the demonstrations of 2013.
} 


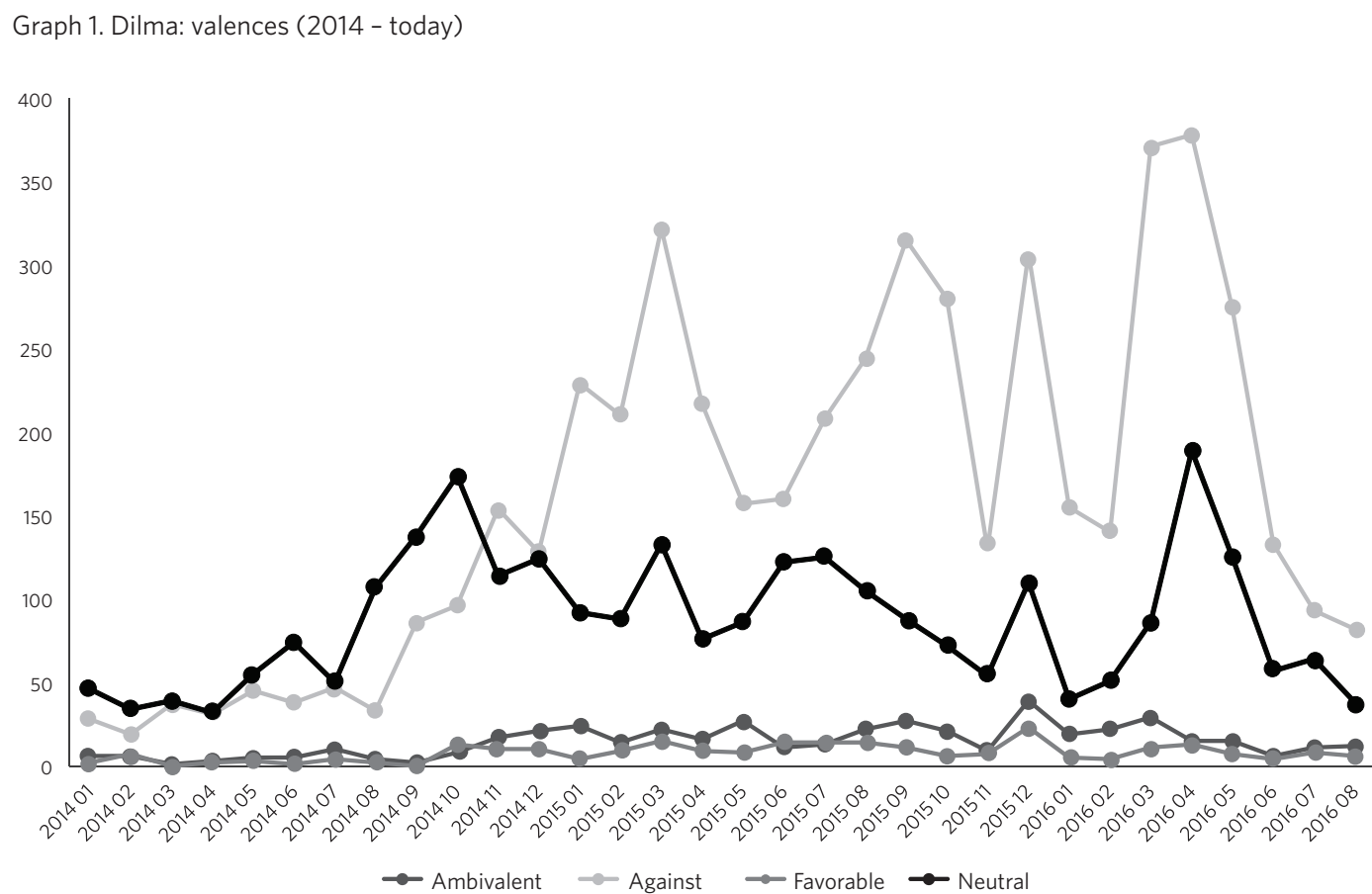

Source: Manchetômetro (Lemep)

The interpretation of graph 1 above is not simple and direct. Firstly, we found out that it is a fact that the articles favorable to or ambivalent about Dilma are rare in the press coverage, so they are not even worth it to be analyzed compared with the number of articles that are against or that adopt a neutral position. Taking a closer look at the neutral and negative articles, the most relevant data to be noticed is the crossover point, in October 2014, when the number of articles against Dilma was higher than the neutral ones. In fact, we would like to call attention to some other details that characterize the press coverage before this turning point. It is worth mentioning that the coverage tone during the entire period of Dilma's campaign is highly negative, i.e., during the less intense months, such as January and June 2014, the number of negative texts regarding the President were similar to the neutral ones. With the beginning of the legal campaign, the media coverage of Dilma increased in volume, but the neutral articles led in relation to the negative ones until the end of the second round. In the month after the second round, on November 2014, the curves started to take a divergent path, with the negative articles increasing consistently, while the neutral ones showed a tendency towards a decline.

The fact that the neutral articles surpassed the negative ones during the election period does not mean that the coverage of Dilma was balanced. As we have already shown in the previous graph and in other previously published texts, the media coverage of Dilma's campaign was extremely negative if compared with that of other candidates. It is important to highlight here the fact that, since the final result of the 2014 presidential election, in November, things have become extremely worse, i.e., the press coverage became even more negative. 
If before the campaign the proportion of negative and neutral articles was of approximately one for one, during the campaign the neutral articles surpassed the negative ones, and after Dilma's victory, the negative articles reached a level three times higher than the neutral articles, consistently remaining like this until impeachment proceedings. We have truly witnessed a media massacre.

What we are showing here using other words is that there was no 'honeymoon' with the major Brazilian press. On the contrary, December 2014 was the last month of the series in which the number of negative articles was the same as the neutral ones. Since then, the number of negative articles increased in January - the first month of the new government - reaching a proportion of more than two times the number of neutral articles (229 to 92 respectively). In March, the number of negative articles was almost three times higher than the neutral ones, with a tendency of relative increase of negative articles until the end of the series.

The peaks of negativity of the press coverage of Dilma coincide with the significant events of the political process that has culminated in her deposition. In March 2015, when the first massive demonstrations in favor of the impeachment proceedings occurred, Dilma's coverage reached records of negativity. In December, when Eduardo Cunha accepted the impeachment process in the Chamber of Deputies, there was another peak of negativity. Finally, the highest level of negativity occurred in the months of March and April 2016, coinciding with all the following events: Lula's coercive conduction, massive demonstrations in favor of the impeachment, Lula's nomination for and suspension from the ministry, and the leakage of the intercept of a phone call between Dilma and Lula. The acceptance of the impeachment proceedings in the senate, which led to Dilma's ouster, can also be considered as part of the events here, as it occurred in the beginning of May and, therefore, in the frontier of April's coverage, the most negative of all the time series.

The skeptical reader must be thinking: but isn't it natural that in periods of political tension, such as the one in which Brazil has been through, the media coverage becomes more negative? In fact, the answer should be no. Each one of the facts mentioned above is the result of a profound moral and practical disagreement. As an example, according to some analysts, the leakage of the intercept of a phone call between Lula and Dilma, perpetrated by judge Sergio Moro, was three times illegal: the phone call was intercepted out of the period previously authorized by Moro; the President was intercepted without the previous authorization by the Brazilian Supreme Court, and the phone call was released by the press. However, the media coverage only showed versions that criminalized Dilma's acts, not giving enough space to those that had a different interpretation of the facts.

\section{Parameters for comparison}

Continuing the conversation with our imaginary skeptical reader, he/she could also ask us whether the negative bias verified in Dilma's coverage was a product of exactly the watchdog attitude of the mainstream media towards the ruling power, which in this case would be President Dilma and her party, the Worker's Party (Partido dos Trabalhadores, PT). Of course that we could say that we have already shown this, based on the data of the media coverage in the last election, that the media in question did not behave as watchdogs; on the contrary, they confirmed a significant bias against left-wing candidates, chiefly against PT, which had already been verified by an exhaustive list of analysts of the media's electoral behavior in the previous presidential elections, throughout the short history of the New Republic. However, the skeptical reader could still insist and 
argue that the previous behavior cannot be used to explain the present, i.e., that the observation of a historical bias does not prove that there was a bias in the period after the election. Yes, at least hypothetically, it is possible that the major media has decided to change its attitude and in fact assume the role of a watchdog of public interests.

The strong bias against Dilma in the postelection context, shown in the previous section, is an evidence that this hypothesis is false. By means of a logic of internal comparison, we tried to show that the intensity of the negativity of the media coverage is not plainly justifiable, as the facts and opinions regarding the actions of great part of the actors of this drama, Dilma, Moro, Lula, Eduardo Cunha, Michel Temer, the Brazilian Social Democratic Party (PSDB), PT etc., are object of great controversy. In other words, there are several interpretations, but the major media has strongly privileged those against Dilma. However, it is still worth conducting a test of external verification. And we will do this by comparing Dilma's coverage with the campaign of her opponent, Aécio Neves (PSDB), president of PSDB, senator and presidential candidate in the last election.

Aécio Neves has a long political career: former federal deputy in Minas Gerais, elected in 1987; president of the Chamber of Deputies, elected in 2001; governor of the state of Minas Gerais for two mandates; senator for the same state since 2011, presidential candidate defeated in 2014 by narrow margin and Brazilian national president of PSDB since May 2013. In addition to his obvious political notoriety as the winner of the opposition, Aécio is also a good parameter of comparison, as there were several accusations of corruption and other illicit practices against him. A brief research on the 2016 press coverage shows the following results listed chronologically:

03/15 - Former senator Delcídio Amaral accused Aécio Neves of receiving bribe from
Furnas, a state-owned electricity company (TALENTO, 2016).

03/15 - Delcídio Amaral also accused Aécio of altering data from the Rural Bank obtained by the Parliamentary Commission of Inquiry (CPI) of the Brazilian Post Office (CANES; PEDUZZI, 2016).

05/03 - Brazil's Attorney General (PGR) Rodrigo Janot sent to the Brazilian Supreme Court requests to investigate Aécio, based on the accusation of former senator Delcídio Amaral, who said that he had to 'hold the fort' when he was the president of the 'Post Office CPI' so that the transactions of the companies of Marcos Valério, who was convicted in the mensalão case, could not be revealed, as they would reach the president of PSDB (MACEDO, 2016).

06/10 - A state-owned company from Minas Gerais established a partnership with the father of senator Aécio Neves (PSDB), Aécio Ferreira da Cunha (1927-2010), when he was still governor of Minas Gerais. The agreement revealed a payment of $\mathrm{R} \$ 250,000$ to grow beans at Cunha's farm in Montezuma (in the north of Minas Gerais). One hundred and fifty thousand reais were delivered in December of that same year. After the death of Aécio's father in 2010, the company was inherited by the current senator and his sister, Andrea Neves (MARQUES, 2016).

06/15 - Former president of Transpetro Sérgio Machado reported in his plea bargain deal in the Lava Jato (Car Wash) Operation, that he had passed on bribe to more than 20 politicians from different parties, including Aécio Neves (FALCÃO ET AL., 2016B).

06/15 - Sérgio Machado also reported that he raised illicit funding for the election of senator Aécio Neves (PSDB-MG) to the presidency of the Chamber of Deputies in 2001 (FALCÃO ET AL., 2016A).

06/18 - Former federal deputy Pedro Corrêa declared that Aécio was responsible for indicating Renato Duque's predecessor in Petrobras Board of Service, Irany Varella, and that Varella took bribe during Fernando 
Henrique Cardoso's government (CASTRO; ROCHA, 2016).

06/25 - Based on documents, contractor Léo Pinheiro, owner and former chief executive of OAS, reported that he paid bribe to aids of the then governor of Minas Gerais, Aécio Neves, during the construction of the Administration City, a work commissioned by Aécio that cost R $\$ 2.1$ billion (CARVALHO; MAGALE, 2016).

07/13 - The Brazilian Federal Police leaked information provided by the cellphone privacy breach of Otávio Marques de
Azevedo, former chief executive of the contractor Andrade Gutierrez, and reveals to have discovered a donation negotiation for Aécio Neves' presidential campaign through Oswaldo Borges da Costa Filho, former chief executive of Codemig and known as the informal treasurer of PSDB-MG (BACHTOLD, 2016).

It is worth noting that all these corruption accusations against Aécio were reported in the same media that we are analyzing in this paper. However, let's take a look at the valence curves of Aécio for the year of 2016:

Graph 2. Coverage of Aécio Neves (2016)

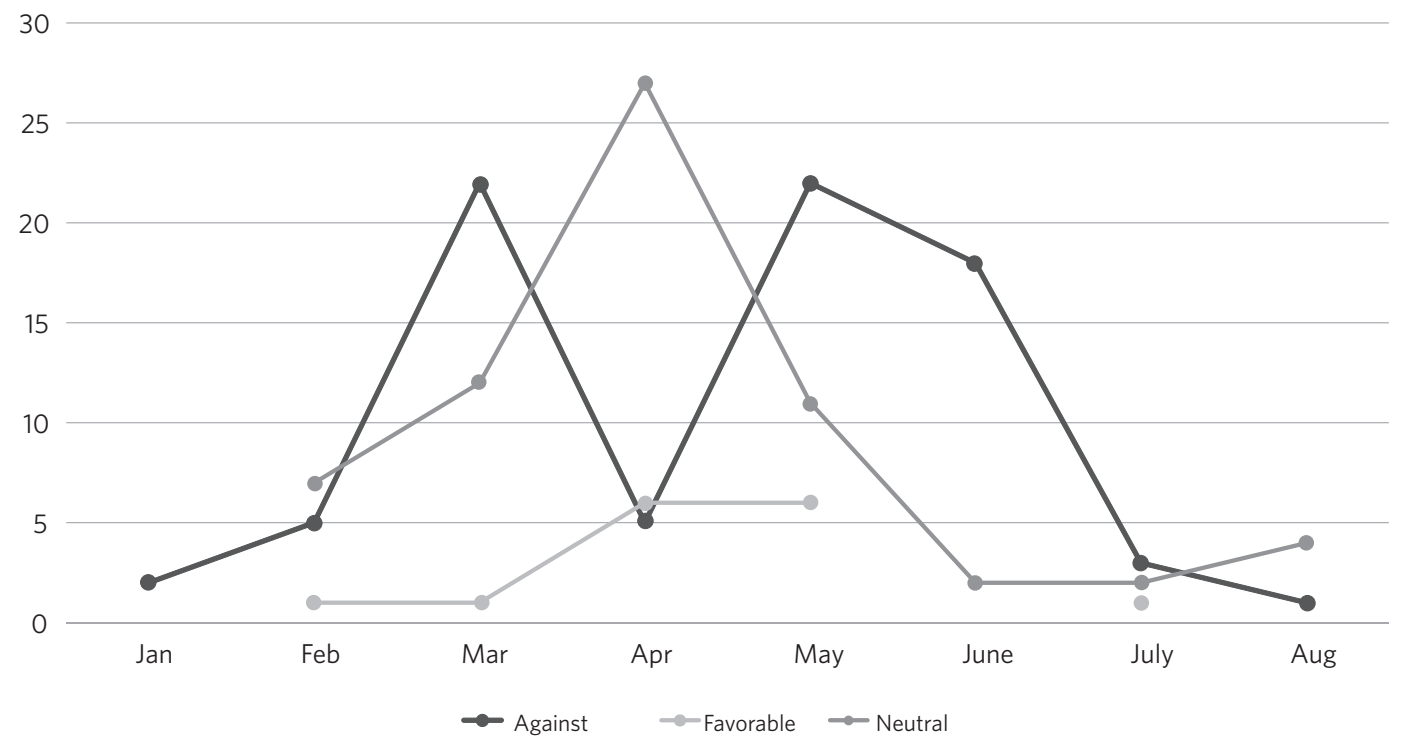

Source: Manchetômetro (Lemep).

Indeed, in spite of being reported by the media, the accusations against Aécio did not seem to have repercussion. We have noticed a pattern of curves in which the neutral articles are almost as numerous as the negative ones or surpass them, even at a moment in which the politician had several accusations of corruption. Graph 3 below, which compares the negative articles about Dilma and Aécio in 2016, clearly shows how the media coverage was unproportioned: 
Graph 3. Articles against Dilma and Aécio (2016)

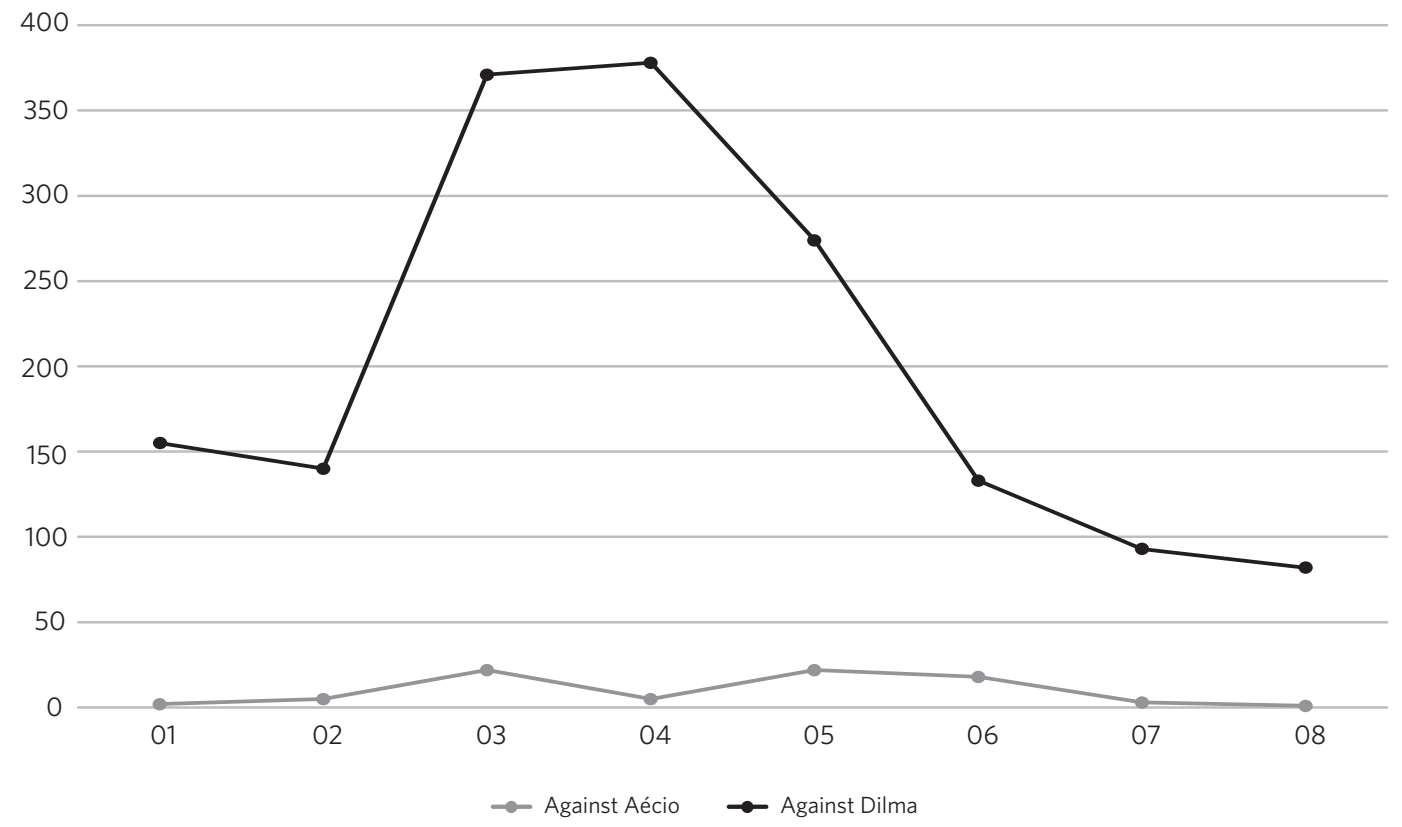

Source: Manchetômetro (Lemep)

The ratio between the number of articles against Dilma and Aécio varies from 7, in June, to 82, in August, when she was removed from office. Aécio had only one article against him. The visual discrepancy between the curves suffices to prove the point, anyway.

\section{Conclusion}

Our exposition about the behavior of the Brazilian media in the context after the presidential election suffices to show that Dilma did not have any 'honeymoon' - a concept created by academics to describe post-election periods in which politicians enjoy a calm period after the elections (JOHNSON, 1983; NORPOTH, 1984). On the contrary, her mandate started to be threatened even before she took office; since the beginning, her government had faced enormous difficulties in the parliament, and the mainstream press assumed a posture even more contrary to the president than during the elections.

The change of the proportion of negative articles still in November, the month following the second round, reveals that the media was not willing to wait for the organization of Dilma's new government. Media coverage goes from 96 articles against the former president in the cover of the three newspapers in October - the last month of the period of elections - to 229 in January, the first month of her second mandate, and climbs to 322 in March. In comparison to October, the number of articles against Dilma tripled.

To prove that our estimates of the media bias is consistent, we compared the numbers of Dilma's coverage with those of Aécio Neves, her main opponent, leader of the opposition in the post-election context and accused of several corruption allegations. The test leaves no doubt that the 
'honeymoon' has never existed. The discrepancy is so significant that it points to a level of media politicization and militancy that is incompatible with modern democracy. However, this subject will not be directly mentioned here.

The impeachment of Dilma was a consequence of several factors, some personal ones, such as the lack of political virtue, the excess of rapacity of her main opponents, such Eduardo Cunha, and the opportunism of politicians such as Renan Calheiros, Michel Temer and many others. Other factors have to do with the system, such as the way that the highly politicized and biased judiciary works, from Moro to the Supreme, as well as the Attorney General's Office (MP) and the Federal Police, government bodies that in several moments were out of control, either because the mechanisms of constitutional control do not exist, such as in the case of the Attorney General's Office or because they do not work, as in the case of the judiciary. However, it is difficult to imagine how all these elements achieved synergy without the active collaboration of the media, by turning Moro and other prosecutors from Curitiba into national heroes, putting pressure on the ministers of the Supreme Court, convoking medium-class people from the big cities to the streets - among them various right-wing, fascist and coupist groups - and selectively persecuting Dilma, Lula and PT, as well as various characters linked to them, with lots of deductions and often groundless accusations.

Post-impeachment Brazil has a government with very little legitimacy, which is implementing a program that systematically reverts all the social and right gains of the last decades; a judiciary system that is in tatters and in the hands of people that act like righteous individuals, but who can barely disguise their political interests, and a society that is terribly unequal and increasingly disappointed with the political and democratic representation. We have gone through many crises in our history, and this one will definitely resolve. However, taking again the virtuous path of spreading the democratic institutions and practices will not be possible if the media continues to be dominated by the same few groups of families who own big media companies. Quality information and access to plurality of opinions are essential to democratic life. Without them, we either die or become democratically ill.

\section{Collaborators}

João Feres Júnior and Luna de Oliveira Sassara were equally responsible for conceiving, planning, analyzing and interpreting the data, as well as for preparing the draft, performing the critical review of the content and approving the final version of this manuscript. 


\section{References}

ARRUDA, L. R. O vôo das notícias: o Jornal Nacional e as eleições 94. 1995. 170 f. Dissertação (Mestrado em Ciências Sociais) - Programa de Ciências Sociais Pontifícia Universidade Católica de São Paulo, São Paulo, 1995.

AZEVEDO, F. Imprensa, campanha presidencial e agenda da mídia. In: RUBIM, A. A. C. (Org.). Mídia e eleições de 98. João Pessoa: Editora UFPB, 2000. p. 31-56.

BACHTOLD, F. Mensagens mostram assédio de políticos a executivo da Andrade. Folha de São Paulo, 13 jul. 2016. Disponível em: <http://wwwl.folha.uol. com.br/poder/2016/07/1791086-mensagens-mostramassedio-de-politicos-a-executivo-da-andrade.shtml> Acesso em: 30 nov. 2016.

CANES, M.; PEDUZZI, P. Delcídio diz que Aécio e Paes agiram em favor do Banco Rural na CPI dos correios. EBC Agência Brasil, Brasília, DF, 15 mar. 2016. Disponível em: <http://agenciabrasil.ebc.com. br/politica/noticia/2016-03/delcidio-diz-que-paese-aecio-agiram-favor-do-banco-rural-na-cpmi-dos >. Acesso em: 30 nov. 2016.

CARVALHO, M. C.; MAGALE, B. Sócio e ex-presidente da OAS relatará propina para assessor de Aécio Neves. Folha de S. Paulo, São Paulo, 25 jun. 2016. Disponível em: <http://wwwl.folha.uol.com.br/ poder/2016/06/1785714-socio-e-ex-presidente-daoas-relatara-propina-em-obra-de-aecio-neves.shtml>. Acesso em: 30 nov. 2016.

CASTRO, F.; ROCHA, M. Pedro Corrêa diz que Aécio indicou antecessor de Duque na Petrobras. G1, Rio de Janeiro, 18 jun. 2016. Disponível em: <http://gl.globo. $\mathrm{com} / \mathrm{pr} /$ parana/noticia/2016/06/pedro-correa-dizque-aecio-indicou-antecessor-de-duque-na-petrobras. html>. Acesso em: 30 nov. 2016.

COLLING, L. Agendamento, enquadramento e silêncio no Jornal Nacional nas eleições presidenciais de 1998. 2000. 133 f. Dissertação (Mestrado em Comunicação e Cultura Contemporânea) - Universidade Federal da
Bahia, Salvador, 2000.

FALCÃO, M. et al. Aécio repassou propinas em troca de apoio na Câmara, diz Machado. Folha de S. Paulo, São Paulo, 15 jun. 2016a. Disponível em: <http://www1. folha.uol.com.br/poder/2016/06/1781941-propinasbancaram-eleicao-de-aecio-a-presidencia-da-camaradiz-machado.shtml>. Acesso em: 30 nov. 2016.

FALCÃO, M. et al. Machado relata propina a mais de 20 políticos de PMDB, PT, DEM e PSDB. Folha de S. Paulo, São Paulo, 15 jun. 2016b. Disponível em: <http://wwwl. folha.uol.com.br/poder/2016/06/1781908-machadodiz-ter-repassado-propina-a-18-politicos-de-pmdb-ptdem-e-psdb.shtml>. Acesso em: 30 nov. 2016.

FERES JÚNOR, J.; SASSARA, L. O. O cão que nem sempre late: o Grupo Globo e a cobertura das eleições presidenciais de 2014 e 1998. Compolítica, Rio de Janeiro, v. 6, n. 1, p. 30-63, 2016. Disponível em: <http:// compolitica.org/revista/index.php/revista/article/ view/232/167>. Acesso em: 29 nov. 2016.

FIGUEIREDO, R. R. Mídia e eleições: cobertura jornalística da campanha presidenciais de 1994. Opinião Pública, Campinas, v. 5, n. 1, p.72-89, nov.1998.

GONÇALVES, E. M. A autonomia dos sentidos como conflito ético na comunicação política. In: NETO, A. F.; PINTO, M. J. (Org.). O indivíduo e suas mídias. Rio de Janeiro: Diadorim, 1996. p. 47-64.

JOHNSON, K. S. The Honeymoon Period: Fact or Fiction? Journalism \& Mass Communication Quarterly, Columbia, v. 60, n. 3, p. 869-876, 1983.

KUCINSKI, B. O ataque articulado dos barões da imprensa: A mídia na campanha presidencial de 1989. In: KUCINSKI, B. (Org.). A síndrome da antena parabólica: ética no jornalismo brasileiro. São Paulo: Editora Fundação Perseu Abramo 1998. p. 105-114.

MACEDO, F. Janot pede investigação contra Aécio, Eduardo Cunha, Edinho, Marco Maia e Vital do Rêgo. Estadão. São Paulo, 02 maio 2016. Disponível em: 
<http://politica.estadao.com.br/blogs/fausto-macedo/ janot-pede-investigacao-contra-aecio-marco-maia-evital-do-rego/>. Acesso em: 30 nov. 2016.

MARQUES, J. Estatal do governo de Minas fez parceria com firma de pai de Aécio. Folha de S. Paulo, São Paulo, 10 jun. 2016. Disponível em: <http://wwwl.folha.uol. com.br/poder/2016/06/1780157-estatal-do-governode-minas-fez-parceria-com-firma-de-pai-de-aecio. shtml>. Acesso em: 30 nov. 2016.

MIGUEL, L. F. Mídia e manipulação política no Brasil: a Rede Globo e as eleições presidenciais de 1989 a 1998. Comunicação \&t Política, Rio de Janeiro, v. 6, n. 2-3, p. 119-138, 1999.

O Jornal Nacional e a reeleição. In:

(Org.). Política e Mídia no Brasil: episódios da história recente. Brasília, DF: Plano Editorial, 2002. p. 61-86.

NORPOTH, H. Economics, Politics, and the Cycle of

Presidential Popularity. Political Behavior, Nova York, v. 6, n. 3, p. $253-273,1984$

TALENTO, M. F. A. Aécio recebeu propina de Furnas, diz Delcídio em delação. Folha de S. Paulo, São Paulo, 15 mar. 2016. Disponível em: <http://wwwl.folha.uol.com. br/poder/2016/03/1750108-aecio-recebeu-propina-defurnas-diz-delcidio-em-delacao.shtml>. Acesso em: 30 nov. 2016.

Received for publication: October, 2016

Final version: November, 2016

Conflict of interests: non-existent

Financial support: non-existent 